\title{
Coercive Diplomacy: The India-Pakistan Case
}

\author{
Vaasu Sharma
}

\begin{abstract}
What are the factors behind successful coercive diplomacy? How Pakistan and India employed coercive diplomacy in attaining leverage, starting from Kargil War till date? How India increasingly resorted to coercive diplomacy against Pakistan especially with the advent of BJP government in 2014? This paper comprehensively deals with these questions by examining the concept of coercive diplomacyand probe the extent of leverage brought by it to the two countries. This paper elucidates the difference between coercion and compellence. Besides, theoretical and conceptual analysis of coercive diplomacy it delves into how India used the coercive diplomacy against Pakistan in different degrees in 5 major conflicts i.e Kargil (1999), Twin Peak Crisis (2001), Mumbai attacks (2008), Uri attacks (2016) and Pulwama terror attacks (2019). In the end, the paper analysis the factors that contributed to the enhanced employment of coercive diplomacy against Pakistan over the years and the crucial role played by US in support of India. Paper also analyse the Indiandilemma in employing coercive diplomacy against Pakistan and how it was overcome. Paper concludes that coercive diplomacy will remain a powerful tool in the arsenal of these nations to extract the desired results.
\end{abstract}

\section{INTRODUCTION}

$\mathrm{I}^{\mathrm{n}}$ n the contemporary international system, the variables, determining the understanding of inter-state relations and crises, have transformed from the state of peace and war to the perceived threat of violence. The space occupied by this new variable is known as a 'grey region' in international relations. Simply speaking, mere threat of violence, which is better known as 'coercive diplomacy', is a new tool in international relations to enforce adversary to give up his claim on his valuable possession or to forbid him from taking control of our valuable possession. This tool can be used against a target state or non-state actors to make them mend their behaviour in conformitywith the desired order.

Thomas Schelling, a prominent international relations theorist states that coercive diplomacy is based on latent violence ${ }^{\mathrm{I}}$, which in fact is extension of Morgenthau theory (1948) that defined the need to combine threat of force with persuasion/compromise as well as reciprocal relationship between diplomacy and force. Notably, focus of the theory was on 'force'rather than 'diplomacy'. Later, Alexander George (1991), developedSchelling's idea of coercive diplomacy and suggested the principle of giving a 'credible' and 'tough' threat of 'punishment' to adversary to convince him to submit to the demands of the threatening state ${ }^{\mathrm{II}}$.As per George coercive diplomacy is an age-old instrument of statecraft that had never been systematized. Itaimsto push adversary to comply/negotiate on demands of coercer besides simultaneously managing to avoid the situation converting into military escalation.
Comparatively, coercive diplomacy holds an edge over use of 'force' because of itsrelatively low price in psychological, economic and political terms.Other significant players in coercive diplomacy include- media, signalling, bargaining and negotiation.

In his book 'Arms and Influence' Thomas Schelling stated that coercive threats may be employed for 'deterrence'or'compellence'.The widely used and known term 'Deterrence', was effectively used during the Cold War. The basic distinction between the two is that while "threat' that compels to act,often requires punishment", hence it comes under compellence, whereasthe "threat extracting'desired' action from target state, without punishment,comes under deterrence"III. Threats under 'Deterrence', forcesan opponent to desist from a certain activity, whereas 'compellence'aims to stop a targeted action of the opponent by the coercer. Comparatively, compellence is considered more difficult to achieve the desired result because of need for continuous punishment, which again, is subject to the capabilities of the coercer.While, compellence,inevitably requires display of some coercive capabilities; deterrence requires only 'threat' or 'bluff' of threat.In case of deterrence, 'inaction' by the target states to maintain the status-quo, becomes a face-saver, whereasunder 'compellence', the target state has to change its behaviour and its prestige along with domestic/international legitimacy suffers a setback because of acceptance ofcoercer's demands.Coercive diplomacy, therefore, is also sometimes called as military coercion, coercive military strategy and strategic coercion.

Coercive diplomacy and compellenceare applicable in various contexts. It is not necessary that any condition which is important to attain success in one context may not hold true in case of another, or there may be case where there is no requirement at all to satisfy suchcondition in the first place . For example, when we apply compellence or coercive diplomacy in the context of humanitarian intervention or peace operations, it is primarily difficult to satisfy the condition of "the compeller having a greater interests and stronger motivation than the other party"becausehere intervention is made as a third party in a dispute of other parties.The success of compellence or coercive diplomacy in such a situation indicate that necessary conditions differ from those in the context deeply related to the interests of the compeller.

A coercive diplomacy is often deemedsuccessful if the coercer state is able to make the target state clearly understandthat the benefits of compliance would be greater than the costs of noncompliance, imposed on it(by the coercer state).Three elements, essential to achieve success in coercive diplomacy 
are: proportionality, reciprocity, and coercive credibility ${ }^{\mathrm{IV}}$. While, proportionality refers to the relationship between the force and leverage applied to theobjectives being pursued, including their scope and nature; reciprocity entails a clear or tacit mutual understanding of linkage between incentives and the discounts, given by the coercer and the target, respectively. Coercive credibility is simply the awareness on the part of target of theserious consequences for noncompliance of the coercer's demands. A good coercive strategy aims to balance these elements along with incorporation ofprevailing international and domestic political contexts, which are more facilitating instead of being restraining ${ }^{\mathrm{V}}$.Moreover, support of major international actors and lesser number of opponents in domestic political landscape of the coercer state, also plays a crucial role in success of the coercive diplomacy.

\section{Coercive Diplomacy in the Context of India-Pakistan Conflict}

The concept of coercive diplomacy arouses greater interest when applied to South Asian nations, especially IndiaPakistan conflict. Notably, both nations simultaneously achieved nuclear capabilities in May 1998.It is pertinent to mention here that,during cold war, coercive diplomacy between US and USSR was based on assumptions that included - safe distance (betweenUS-USSR);safenuclear technology;safety from 'Mutually Assured Destruction'; and ideology acknowledging unaffordability of self-destruction. In contrast India and Pakistan are close neighbours; neither of themheavy mega city-busting bombs or that could trigger MAD; the safety of nuclear technologyremain questionable; and Pakistan is likely tocollapse, with jihadi militias challenging its sovereignty. Further, there is a danger of 'reverse indoctrination' of the Pak-Army and its capability to protect the nuclear arsenal.

In Indian context nuclear deterrence is a crucial element while enlisting compellent measures against Pakistan. The very element gives leverage to Pakistan on non- complianceof Indian demands, including stopping of state-sponsored terrorism. Following Pak-sponsoredterrorism/insurgency, India resorted to coercive diplomacy. It started during Kargil crisis (1998) and since then is being pursued with more vigour and strategy. Apart from global factors, including US role, 5 major crisesviz. Kargil conflict (1999); Twin Peak Crisis (2001); Mumbai attacks 26/11 (2008); Uri attacks (2016); and Pulwama attack (2019), can be attributed to the adoption of coercive diplomacy by India against Pakistan. The Kargilconflict not only hardened the mutual distrust but alsolaid foundation for the other 4 events, the subject of our case studies.

\section{Kargil Crisis (1999)}

Following declaration of nuclear capabilities by India and Pakistan, the Kargil war (May-July, 1999), was the first limited conflict between the two countries. After first attack on Indian patrol party, it became obvious that the intruders firing on Indian troops were trained troops from the Pakistani
Northern Light Infantry (NLI). Realising this major military incursion, India resorted to both military and diplomatic initiatives and eventually pushed out Pakistani intruders from Kargil in 2 months' period. Despite being categorised as a mini-war, Kargil war, with approximately 750-950 casualties was instrumental in laying foundation for Pakistan's future mischievous/terror activities ${ }^{\mathrm{VI}}$.

Pakistan's disregard for Indian sovereignty can be ascribedto Pakistan's perceptions including:safety ofits nuclear umbrella;perceived timidity of Indian politicians; and assumption, backed by the concept that 'winner takes all', at the LoC. Despite the then Indian PM Atal Bihari Vajpayee's peace and diplomatic overtures (February 1999) the PakArmy believed that they would alter the LOC in their favour by the time bilateral negotiations would conclude to cease the hostilities. They thought that in line with coercive diplomacy, they would control heights along NH 1A and would compel India to negotiate on Siachen area. Pakistan miserably failed to calculate Indian military response to recapture all the heights, with artillery and air power, not seen, since $1971^{\mathrm{VII}}$. The conflict made clear that despite nuclear deterrence, there are options to exploit some strategic measures. From Indian point of view, Kargil, was a defensive war and cannot be strictly put under the compellent diplomacy, requiring military punishment.However, after this war, Indian strategies gradually begin to coerce Pakistan both militarily and diplomatically.

When domestic militant groups were replaced by Paksponsored militants, including foreign nationals in Kashmir, India became firm and focused on its demand of stopping cross-border terrorism and demobilisation of militant outfits, which India constantly raises at various regional/international forums. Initially, Indian attempts to link Pakistan with terrorism failed but after $9 / 11$ attacks international community took notice of the terror activities, getting support from Pakistan and its neighbouring Afghanistan.

\section{Twin Peak Crisis 2001 (Operation Parakram)}

The twin peak crises refer to twin Pak-sponsored attacks i.e. attack (December $\left.13^{\text {th }}, 2001\right)$ on Indian Parliament and attack (May 14, 2002) at KaluchakArmy Camp in Jammu, during the period between December 2001 and October 2002,due to which Indo-Pak war almost became a reality. Five armed militants infiltrated the Indian Parliament to make the government dysfunctional and killed 14 besides injuring 22 others. Symbolism of attack than the casualties was more significant, which happened just four months after the 9/11 attacks and two months after a similar attack in the Kashmir state assembly in Srinagar (where 38 died).Indian Intelligence confirmed the involvement of terrorist organizationsLashkar-e-Taiba and Jaish-e-Mohammed, both based in Pakistan, backed by Pakistani Inter-Services Intelligence Agency (ISI), in the attack. The attack led to a 10-month face off between India and Pakistan, with India launching military 'Operation Parakram'.Both sides deployed around one million 
soldiers at borders and LOC inKashmir, in a high state of alert, even making US intelligence believe the likelihood of large-scale war ${ }^{\mathrm{VIII}}$.

The Indian Cabinet Committee on Security considered various options, including 'surgical strikes' into Pakistan-held territory or rapid escalation to teach Pakistan a lesson. However, owing to paucity of time and difference of opinions, it eventually decided to mobilize its three advanced strike corps and keep them ready for an attackon further deterioration of the situation ${ }^{\mathrm{IX}}$. This middle approach satiated both domestic audience and hardliners as well as others. The mobilisation alsosignalled India's seriousnessin demanding Pakistan to end its terror infrastructure.

This decision was primarily based on two key assumptions, viz. (i) India's a strong conventional superiority over Pakistan, as manifested duringKargil warwhen Indian troops defeated Pak intruders, even inhostileconditions; and (ii)Dismissal by Indian leaders, of Pak's 'first nuclear strikethreat' asserting that (and channeling Kenneth Waltz) while India was capable of absorbing thefirst strike, it would retaliate withhugepunishment on Pakistan, threatening its existence ${ }^{\mathrm{X}}$. By this logic, they believed thatPakistan would desist from first use of nuclear weapons.

Significantly, Indian coercive strategy was not confined to Pakistan but also to incite international, particularly US' support in case the conflict escalated. Acknowledging important role of US in de-escalating Kargil conflict, as well as the adverse consequences of Indo-Pak war on US' regional interests, India was keenthat US put pressure on Pakistan to endits anti-India terror structure. By threatening war, India was also firm to compel Pakistan to extradite 20 criminals/terrorists.Thus, an important element in India's coercive strategy was to exploit US' interests and concerns ${ }^{\mathrm{XI}}$. Importantly, India, in contrast to Pakistan, was delicately using the war-threat to musterinternational support against Pakistan.

In absence of option, Pakistan also mobilised its forces on eastern border and increased troops in Pak-occupied Kashmir by re-deployment of troops on its western border. Despite in response to Indian threat of war Pak's a retaliatory action was based onvarious assumptions, including: rejecting India's conventional superiority, believing that Kargil's losswas the outcome of civilian betrayal of combat objectives ; and that Pakistan was roughlyin parity with India at their shared borders.

Indian coercive diplomacy was comparatively not considered much successful as it did not follow its two key elements viz. Indian demands far exceeded than willingness and motivation on part of Pakistan to comply; and the coercing power (India) offered few rewards to ensure adversary's compliance ${ }^{\mathrm{XII}}$. Moreover, India's military threats lacked credibility. While, the nuclear capability emboldened Pakistan to persist with its anti-India terror structure, it also restrained India's response to Pakistan's infiltration of terrorists. India's reluctance to expand the area of Kargil conflict also convinced Pakistanthatits nuclear capability had effectively checked India's conventional military superiority. Hence, inevitably, India failed in convincing Pakistanof escalatory action against Pakistan, an essential element for a successful coercive diplomacy.

However India did achieve a little success as Pakistan banned some of the terroroutfits and arrested their leaders, besides freezing their accounts and closing some terrorist camps in Pakistan-Occupied Kashmir. Pak-infiltration bids also witnessed a slide.

Twin-Peaks' case study clearly makes us understand that coercive diplomacy, both conventional and nuclear, plays an important role in escalation/de-escalation of a conflict.While, India's belief of its conventional superiority and second-strike nuclear capability gave it confidence that Pakistan would submit to its demands and behave accordingly, Pakistan relied on in its first-strike threat and tactical conventional parity with India, which made it to act in contrast to Indian expectations. Both sides' aggressive assumptions in context of conventional and nuclear threats enhanced the risk of war. In absence of a third-party, like, US, wherein Colin Powell, Richard Armitage, and other US diplomats brokered to check the situation from moving towards real Indo-Pak war on ground.

Twin-Peaks also showcased the then Pak President Musharraf's action of allowing continuance of cross-border infiltrations to appease his domestic audience, which supported LeT, despite promising contrary to international audience. On the other hand, when required to stop infiltration of non-state actors after the Kaluchak incident (wherein 38 Indian army personnel were killed in 2002),Musharraf temporarily stopped the same. These events clearly suggestthat Pak agencies were employing mixed strategies, while resorting to coercion and diplomacy ${ }^{\mathrm{XIII}}$.

Following India's somewhat success (2001) in extracting desired action from Pakistan, while failing to do so after Kaluchak incident (2002) due to non-mobilisation of forces at that time, India reviewed its conventional military doctrine, to rectify these loopholes.Later, a new mobilization doctrine called as 'Cold Start' was announced in 2004 that intended tostimulate a retaliatory conventional strike against Pakistan before the intervention of international community.It also sought todeny Pakistan any justification to transform the clash intonuclear war ${ }^{\mathrm{XIV}}$. 'Cold Start' doctrine, (based on lessons fromKargil and Twin-Peaks)established thatonly quick and effective action by Indian army could coerce Pakistani behaviour, to India's advantage. However, 'Cold Start'lacked pragmatic approach because even Indian armed forces did not have consensus on its status and was not even formally approved by the Indian Ministry of Defense, and Cabinet Committee on Security ${ }^{\mathrm{XV}}$.

Consequently, the doctrine remained good only on paper.Meanwhile, in absence of a comprehensiveIndian strategy to counter Pak-sponsored terrorism, Pakistan 
exploitedthis lacuna and persisted with its terror attacks in whichits sleeper cells across India facilitated these attacks, that later resulted in Mumbai terror attacks in 2008.

\section{Mumbai Attacks (26/11 Attacks)}

The Mumbai or26/11 attacks (November 2008) were carried out by a group of 10 Pak-based 'Lashkar-e-Taiba' (LeT) terrorists. In a series of 12 coordinated shooting and bombing attacks at different locations, 164 people were killed and 308 were injured during 4 days siege of Mumbai ${ }^{\text {XVI }}$. It was widely condemned by international community. The attacks exposed the practicality of 'Cold Start' doctrine as unlike 2001, India could not use its coercive stance to compel Pakistan, change itsbehaviour. Notably, Indian strategy failed on two counts viz. failure to carry out effective retaliation despite publicly announcing the strategy; and public announcement of strategy provided Pakistan a justification to increase its nuclear arsenal to counter Indian supremacy in conventional war. Thus, credibility of Indian coercive deterrence was seriously exposed.

Despite proofs given by India and the US on involvement of Pak nationals, Pakistan rejected allegations of its involvement though it half-heartedly agreed to take action against LeT or Jamaat-ul-Dawa.

'Cold Start'sfailure convinced India that it cannot depend only on a conventional deterrent threat to prevent cross-border incursions. However, the Pak terrorists had carried the attack, assuming that Pakistan's 'first-use' nuclear strategy would deter India from attacking Pakistan in retaliation. Thus, Pakistan's nuclear deterrent proved as an umbrella for terror groups to operate without any fear. India's credible response to the attacks only confirmed terrorists' assumption. Significantly, Mumbai attacks not onlydepictedgrave shortcomings in India's internal security system, both, organisationally and technically, but also raised question over effectiveness of US' crisis management skill.US's reputation of an honest broker was also suffered as 6 US citizens were in the casualty list. US' credibility as a crisis manager further suffered setback from Pakistan's angle after US initiated New Steps in Strategic partnership (NSSP),especially, mutual assistance in civilian-nuclear developments to the discomfiture of Pakistan ${ }^{X V I I}$.

Indian PM owing to technical and other constraints decided to put non-violent pressure on India by mustering global support against Pakistan.However, UN was not influenced by this support and did not pass any resolution as was done during 9/11 incident or London subway bombings (2005). Moreover, Pakistan also escapedeconomic sanctions.

Furthermore, for Pakistan, denial was primarily a globally face-saving measure or it would have been put under pressure to take several corrective measures which would have further deteriorated its delicate domestic political landscape. In fact, India's pragmatic decision to scale down its demands from Pakistan also stems from acknowledgement of the reality that
Pakistan to an extent was not in full command to check domestic radicalisation and terrorism.

Post 26/11 and Shift in India's coercive strategy: Uri Attacks \& Surgical Strikes (2016)

Following world-wide condemnation of Pakistan for perpetrating attacks in Mumbai, Indian Army establishments in $\mathrm{J} \& \mathrm{~K}$, became the new targets for Pak-supported militants.Meanwhile, India and majority of world was getting uncomfortable with terror attacks, particularly Post 26/11. Hence, while, US intervened immediately to damage-control after both Kaluchak and also 26/11, it did not intervene after Uri attack of September $2016^{\text {XVIII }}$.

On September 18th, 2016, Four Pak-based Jaish-eMohammad terrorists, after infiltrating fromPir-Panjal side, attacked Indian Army Brigade Headquarters at Uri. 19 soldiers were killed in a sudden hand-grenade and firing attack. It was the deadliest attack since Kaluchak incident (2002). The attackers were carrying military-grade incendiary weapons, difficult to get without official assistance ${ }^{\mathrm{XIX}}$. Despite Pak-denial, India was sure of its involvement. Hence, shedding its 'strategic restraint' approach, India on diplomatic front, firstly suspended all activities with South Asian Association for Regional Cooperation (SAARC), and militarily it carried out surgical strikes within Pakistan Occupied Kashmir (PoK) against terrorists launch camps. Significantly, India publicly announced (September 29th, 2016) that itcarried out surgical strikes within $\operatorname{PoK}^{\mathrm{XX}}$. This depicted a shift in Indian strategy from negotiations to aggressive coercive diplomacy. Furthermore, India initiated a diplomatic offensive to isolate Pakistan globally, including: withdrawal from SAARC (followed by Afghanistan, Bangladesh and Bhutan); ban on Pak actors/techniciansby the 'Indian Motion Pictures Association'XXI.

Factors contributing to shift Indian strategy for a new aggressive approach, which India has been avoiding, can be attributed to a mix of: increasing domestic anger against Pakistan after Mumbai attacks; India's enhanced standing at global platforms; and deteriorating US-Pakistan relations. Importantly, nuclear deterrence, which was hitherto holding India back from its aggressive stance against Pakistan, was thoroughly exposed after Kargil war.

Uri, in a significant manner, depicted Indian capacityto control the "spiral" effect of its aggression. Of course, a major reason for Indian confidence lies in international support to India. At the 71st session (September 2016) of the UNGA, India termed Pakistan as hub of terrorism and its various cities as the Ivy League of Terrorism. Pakistan felt that it was increasingly getting isolated in the world. Later, on behest of India, two US lawmakers, Congressmen Ted Poe and Dana Rohrabacher introduced (September 20, 2016) a Bill in the US House of Representatives to put Pakistan as State Sponsor of Terrorism and a safe haven for international terrorism. However, the Bill could not gather requisite support within the Congress but it came as a kind of deterrence to Pakistan, 
fearing cut in US aid, to keep itself away from such daring terror acts in future.

US National Security Advisor Susan Rice assured (September 28)Indian National Security Advisor Ajit Doval of US' support and strongly condemned Pakistan's actions through a press release, which neither referred to Kashmir, nor encouraged any dialogue between the two countries. It asked Pakistan to disarm the militants operating within its territory. This support helped India in making public announcement of surgical strikes.

Significantly, after ensuring that to achieve the desired results, it has calibrated the requisite punishment, India in order to check escalation as well asassure Pakistan, clarified that India do not intend to carry further strikes.

To put further pressure,India questioned Human Rights Violationsin Balochistanby Pak security forces in global and regional platforms.Post-Uri attacks, Indian announcementto considerasylum application of the secessionist group Balochistan Republican Party (BRP) leader,Brahamdagh Bugti, made Pakistan apprehensive of India and a fear of Balochi insurgency if it did not stop proxy terror attacks in Kashmir ${ }^{\text {XXII. }}$.

\section{Pulwama terror attack \& Balakot Air Strikes (2019)}

After three years of Uri surgical strikes, Pak-based J-e-M terrorists again attacked (February 14, 2019) Indian Paramilitary convoy in Pulwama (Kashmir) by triggering a roadside blast and killed 40 soldiers. India, taking more aggressive line, instead of taking retaliatory action inside Pak occupied Kashmir like in Uri surgical strikes decided to punish terror groups and give a signal to Pakistan by striking deep within Pak territory where J-e-M training camps were being operated. Indian Air Force launched (February 26, 2019) a retaliatory air-strike at J-e-M training complex Balakotin the Khyber Pakhtunkhwa province of Pakistan. It was first such strike within interior Pakistan,after Indo-Pak war (1971). Though Pakistan retaliated with an airstrike next day in Indian Kashmir wherein besides Pakistan's F-16 fighter aircraft and an Indian Air Force MiG-21 fell within Pakistani side of border.An Indian pilot captured by Pakistan was released two days later to officially defuse the crisis ${ }^{\text {XXIII. }}$.

Indian retaliatory action in Balakot was a marked departure from Indian response to 2008 Mumbai attacks. This response, in succession to Uri surgical strikes, gave an ample indication to Pakistan that India has left behind the pre-2016 strategic restraint and it will now employ coercive diplomacy to check Pak-sponsored terrorism. Importantly, by releasing Indian pilot to diffuse tensions, Pakistan shed its threat of invoking nuclear deterrence to stop Indian as well as US' anti-Pak response. Notably, US' 'behind the scene' diplomatic pressure on Pakistan to de-escalate, also played an important role in release of Indian pilot.

Balakot Airstrikes perfectly displayedcoercive diplomacy, in form of air strikes. For any opponent, like Pakistan, who depends upon traditional military strategyand communications, air strikes were the most effective option as coercive punishment. Islamabad's diplomatic options after Pulwama remained limited as its supporter China, concerned about the China-Pakistan Economic Corridor, maintained distance and asked both sides to exercise restraint.

After Balakot strikes, India made it clear that its strategic restraint should not be taken as its weakness. While, India as a policy decision during Kargildid not cross the Line of Control, but in 2016 surgical strikes, India crossed the LoC for attack in territory under Pakistan's governance, but which technically belonging to India i.ePakistan Occupied Kashmir (PoK). In case of Balakot strikes the attack was indeed inside Pak territory.

Analysis

India's progressive graph on adoption of methods of coercive diplomacybecomes apparent after we analyse incidents of Kargil war, Twin Peak Crisis, 26/11 attacks, Uri and Balakot. Simply speaking, intensity ofIndian retaliation increased with every consecutive incident. Factors that contributed to India's progressive coercive diplomacy, are: enhanced strategic cooperation between India and US;India's enhanced credibility in global affairs; and assumption of power by a strong and decision-taking government in India since 2014.

US played a major role in preventing the situation transforming into military escalation or even reaching at nuclear flash point after every Indian retaliatory action, ranging from Kargil to Mumbai attacks or surgical strikes in Uri and Balakot. US was able to fill in the communication gap that developed, because of increasing trust deficit between India and Pakistan.The 1999 Lahore Declaration and 2000 Agra Summit, the two events preceding Kargil and Twin Peaks crisis, respectively, added to this trust deficit.Further, US was also able to maintain its unbiased, honest and rationale image, acceptable to both India and Pakistan, which enabled US to play its role smoothly.

A close analysis shows that India was rather indecisive whether to go for conventional deterrence or coercive diplomacy (mobilisation) because while during Kargil conflict, conventional deterrence was successful for India but it could not remain long lasting and Pakistan responded with Twin Peaks and Mumbai attacks. India though again decided to go for conventional deterrence but only with the help of US-led diplomacy, India could sail smoothly through the situation. However, this again could not act as long term deterrence for Pakistan.

Hence, India learnt the lesson that, it would have to depend on its own ability to coerce Pakistan. On the other hand, developments in Afghanistan, coupled with 2008 Mumbai attacks led to deterioration in relations between Pakistan and US and Pakistan believed that US may be biased towards India as negotiator. India is now moving towards embracing the new coercive strategy to compel Pakistan change its 
behaviour, through punishments with actions like surgical air and ground strikes.

India's increasing confidence to take coercive steps without attracting Pak's retaliation as manifested bynot only by Uri and Balakot strikes but also subsequent public announcement to this effect. India's this enhanced response capability is in conformity with Jentleson's assertion that "a coercive action succeeds more often, when the response is proportional to the provocation"XXIV . Earlier, Indianpolicy, based on conventional mobilisationwas apparentlyless disproportionate as compared to Pak-backed cross-border terrorism.Moreover, Policy'sassumption that mobilization may transform Pakbacked militant's behaviourwas very weak. Further, continuance of Indian policy of surgical strikes against militant targets within Pakistan, would convey the tough message to Pakistan that safety of its 'strategic non-actors' depends upon Pakistan's behaviour.

In contemporary times, multilateral support is an essential ingredient for successful coercive diplomacy,similar toeconomic sanctions, wherein political support and legitimacy is essential.More the target state is incapable to break this multilateral support, more the coercive diplomacy is considered successful and India precisely ensured a solid support for its coercive actions.

\section{CONCLUSION}

India'sadoption of coercive diplomacy commenced with Kargil crisis (1999) with certain limitations, though it continued to get upgraded in response with every successive Pak perpetrated terror activity.In the initial phase, global community urged Pakistan to disallow its territory for usage of terror activities but several countries also urged India to exercise restraint, when in response to Uri attacks (2016) India carried out surgical strikes on terrorist launch pads in Pakistani Kashmir.After Trump's assumption (2017) of power, India managed to get support for greater escalatory action favourable international climate and PM Modi's imaginative coercive diplomacy made Balakot air strikes extremely successful.

The contemporary world is more engagedin coercive diplomacy with emphasis on avoiding real turf war. 'Credible' deterrence and 'projected' deterrence are two faces of the Coercive diplomacy, which reflects better image of indirect warfare.Better utilisation of media, social media, electronicand diplomatic forums are important as manifested by Tibet and Kashmir issues, in context of coercive diplomacy. US, China and Pakistan pursuing coercive diplomacy against India at various occasions to further their interests are prime example of this strategy. In distinct cases

of US' coercive diplomacy, it becomes apparent thatinstead of direct military action, coercion or threats of credible military action was more advantageous. In fact, Coercive Diplomacy remainsan important tool to safeguard and promote the core national interests of a country. It was recently manifested by
India also with modernisation of its arms and equipment, including acquisition of Rafale fighter jets from France, which will be a big coercive deterrent for Pakistan.Furthermore, with the Biden administration in power, with focus on internationalism as opposed to Trump's isolationism, it would be interesting to witness how India would manage its relations with US to employ the coercive diplomacy against Pakistan to further its interests in the sub-continent, particularly in Afghanistan where Pakistan,riding on Chinese support,is challenging the US and Indian interests.

\section{BIBLIOGRAPHY}

[1] SCHELLING, T. (1966). Arms and Influence. Yale University Press. Retrieved August 5, 2020, from www.jstor.org/stable/j.ctt5vm52s

[2] Levy, J. S. (2008). Deterrence and Coercive Diplomacy: The Contributions of Alexander George. Political Psychology, 29(4), 537-552. doi:10.1111/j.1467-9221.2008.00648.x

[3] Upadhyay, A. (2019). Coercive diplomacy against Pakistan: Options and effectiveness in non-nuclear conflict space in current times. New Delhi: KW Pvt.

[4] Jentleson, B. (2006, December). Coercive Diplomacy: Scope and Limits in the Contemporary World. Retrieved August, 2020, from https://stanleycenter.org/publications/coercive-diplomacy-scopeand-limits-in-the contemporary-world/

[5] Khan, Aateeb (2018). For One Tooth, the Entire Jaw: CrossBorder Extremism, Coercive Diplomacy, and the India-Pakistan Security Dyad. Honors thesis, Duke University. Retrieved from https://hdl.handle.net/10161/16492.

[6] Ganguly, S., \&amp; Kraig, M. R. (2005). The 2001-2002 IndoPakistani Crisis: Exposing the Limits of Coercive Diplomacy. Security Studies, 14(2), 290-324. doi:10.1080/09636410500232958

[7] Bhattacharya, P. (2009, December 14). Army and IAF face off over new war plan. Retrieved August, 2020, from https://www.indiatoday.in/latest-headlines/story/army-and-iafface-off-over-new-war-plan-62958-2009-12-14

[8] PTI / Jul 24. (2008, July 24). India dismisses Pak talk of arms race due to N-deal: India News - Times of India. Retrieved August, 2020, from https://timesofindia.indiatimes.com/india/Indiadismisses-Pak-talk-of-arms-race-due-to-Ndeal/articleshow/3276347.cms?referral=PM

[9] Safi, M. (2016, October 09). Indian films banned, Pakistani actors ejected - how the Kashmir crisis is hitting Bollywood. Retrieved August, 2020, from https://www.theguardian.com/world/2016/oct/09/indian-filmsbanned-pakistani-actors-ejected-how-the-kashmir-crisis-is-hittingbollywood

[10] Mukherjee, R. (2019, October 01). Climbing the Escalation Ladder: India and the Balakot Crisis. Retrieved August, 2020, from https://warontherocks.com/2019/10/climbing-the-escalationladder-india-and-the-balakot-crisis/

\footnotetext{
${ }^{\mathrm{I}}$ Schelling, 1966

IILevy,2008 (Pg 540)

IIIUpadhyay.2019 (Pg 5)

${ }^{\mathrm{IV}}$ Jentleson,2006 (Pg 3)

VJentleson,2006 (Pg 4)

${ }^{\mathrm{VI}}$ Khan,2018 (Pg 15)

VII Upadhyay,2019 (Pg 16)

VIIIKhan,2018 (Pg 31)

${ }^{\mathrm{IX}}$ Khan,2018 (Pg 31)

${ }^{\mathrm{X}}$ Khan,2018 (Pg 32)

${ }^{\mathrm{XI}}$ Khan,2018 (Pg 32)

${ }^{\mathrm{XII}}$ Ganguly \& Kraig, 2005 (Pg 311)

XIIIKhan,2018 (Pg 38)
} 
International Journal of Research and Scientific Innovation (IJRSI) |Volume IX, Issue I, January 2022| ISSN 2321-2705

\footnotetext{
${ }^{\mathrm{XIV}}$ Khan,2018 (Pg 41)

${ }^{\mathrm{XV}}$ Bhattacharya,2009

${ }^{\mathrm{XVI}}$ Upadhyay,2019 (Pg 21)

XVIIPTI, 2008

XVIIIUpadhyay,2019 (Pg 37)

${ }_{\mathrm{XIX}}$ Khan,2018 (Pg 51)

${ }^{x}$ Khan,2018 (Pg 51)

${ }^{\mathrm{XXI}}$ Safi,2016

XXIIUpadhyay,2019 (Pg 51)

XXIII Mukherjee,2019

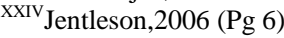

